\title{
Mariniflexile aquimaris sp. nov., isolated from seawater, and emended description of the genus Mariniflexile Nedashkovskaya et al. 2006
}

Correspondence
Jung-Hoon Yoon
jhyoon69@skku.edu

The genus Mariniflexile, a member of the family Flavobacteriaceae, phylum Bacteroidetes, was proposed by Nedashkovskaya et al. (2006) with Mariniflexile gromovii, isolated from a sea urchin, as the sole recognized species. Mariniflexile fucanivorans was subsequently described from a water-treatment facility recycling the effluent of an alginate-extraction plant (Barbeyron et al., 2008). In this study, a novel bacterial strain, designated HWR $-17^{\mathrm{T}}$ and isolated from seawater off Hwangdo, an island of the Yellow Sea in Korea, is described. Comparative 16S rRNA gene sequence analysis indicated that strain HWR-17 ${ }^{\mathrm{T}}$ was most closely related phylogenetically to members of the genus Mariniflexile. The aim of the present work was to determine the exact taxonomic position of strain HWR$17^{\mathrm{T}}$ by using a polyphasic characterization that included

The GenBank/EMBL/DDBJ accession number for the $16 \mathrm{~S}$ rRNA gene sequence of strain $\mathrm{HWR}-17^{\top}$ is $\mathrm{HQ} 144198$. the determination of phenotypic properties, a detailed phylogenetic investigation based on $16 \mathrm{~S}$ rRNA gene sequences and genetic analysis.

Strain HWR-17 ${ }^{\mathrm{T}}$ was isolated by the dilution plating technique at $25{ }^{\circ} \mathrm{C}$ on marine agar 2216 (MA; Difco) and cultivated routinely on MA at $30{ }^{\circ} \mathrm{C}$. M. gromovii KCTC $12570^{\mathrm{T}}$ and $M$. fucanivorans DSM $18792^{\mathrm{T}}$ were used as reference strains for DNA-DNA hybridization, fatty acid and polar lipid analyses and a number of other phenotypic tests. Cell morphology was examined by using light microscopy (DP70; Olympus) and transmission electron microscopy (CM-20; Philips). The latter technique was also used to assess the presence of flagella on cells from an exponentially growing MA culture. For this purpose, the cells were negatively stained with $1 \%(\mathrm{w} / \mathrm{v})$ phosphotungstic acid and the grids were examined after being airdried. Gliding motility was investigated as described by Bowman (2000). The Gram reaction was determined by 
Table 1. Differential phenotypic characteristics of strain HWR$17^{\top}$ and the type strains of the two Mariniflexile species

Strains: 1, M. aquimaris sp. nov. HWR- $17^{\mathrm{T}} ; 2$, M. gromovii KCTC $12570^{\mathrm{T}}$; 3, M. fucanivorans DSM $18792^{\mathrm{T}}$. All data were obtained in this study except for Gram-staining, optimal temperature, flagellar motility, catalase activity, susceptibility to antibiotics and DNA $\mathrm{G}+\mathrm{C}$ content of reference strains; these data were taken from Nedashkovskaya et al. (2006) and Barbeyron et al. (2008). +, Positive; -, negative; w, weakly positive. All strains are positive for the following: catalase activity; hydrolysis of aesculin and Tweens 20, 40 and 60; utilization of D-glucose, D-fructose, D-galactose, D-mannose and D-xylose; acid production from D-xylose, D-fructose, D-glucose and D-galactose; and activity of alkaline phosphatase, esterase (C4), leucine arylamidase, acid phosphatase and naphthol-AS-BI-phosphohydrolase. All strains are negative for the following: Gram staining; flagellar motility; production of flexirubin-type pigments; oxidase activity [opposite result reported by Nedashkovskaya et al. (2006) for M. gromovii KCTC $12570^{\mathrm{T}}$ ]; $\mathrm{H}_{2} \mathrm{~S}$ production; nitrate reduction; hydrolysis of urea and xanthine; utilization of trehalose, acetate, citrate, succinate, benzoate, L-malate, pyruvate, salicin, formate and Lglutamate; acid production from myo-inositol, D-ribose, melibiose, melezitose, trehalose, and raffinose; susceptibility to streptomycin and kanamycin; and activity of lipase (C14), trypsin, $\alpha$-chymotrypsin, $\alpha$ galactosidase, $\beta$-galactosidase, $\beta$-glucuronidase, $\alpha$-mannosidase and $\alpha$-fucosidase.

\begin{tabular}{|c|c|c|c|}
\hline Characteristic & 1 & 2 & 3 \\
\hline Optimal growth temperature $\left({ }^{\circ} \mathrm{C}\right)$ & 30 & $23-25$ & 25 \\
\hline Gliding motility & - & + & + \\
\hline \multicolumn{4}{|l|}{ Hydrolysis of: } \\
\hline Casein & + & + & - \\
\hline Gelatin & - & + & - \\
\hline Hypoxanthine & - & - & + \\
\hline Starch & + & - & $\mathrm{w}$ \\
\hline Tween 80 & + & - & + \\
\hline L-Tyrosine & + & + & $\mathrm{w}$ \\
\hline \multicolumn{4}{|l|}{ Utilization of: } \\
\hline L-Arabinose & + & - & - \\
\hline Cellobiose & + & - & + \\
\hline Maltose & $\mathrm{w}$ & - & - \\
\hline Sucrose & + & + & - \\
\hline \multicolumn{4}{|l|}{ Acid production from: } \\
\hline L-Arabinose & + & - & - \\
\hline Cellobiose & + & - & + \\
\hline Lactose & - & - & + \\
\hline Maltose & + & - & + \\
\hline D-Mannitol & + & $\mathrm{w}$ & - \\
\hline D-Mannose & $\mathrm{w}$ & + & + \\
\hline L-Rhamnose & - & $\mathrm{w}$ & - \\
\hline Sucrose & + & + & - \\
\hline \multicolumn{4}{|l|}{ Susceptibility to (per disc): } \\
\hline Ampicillin $(10 \mu \mathrm{g})$ & - & + & + \\
\hline Tetracycline $(30 \mu \mathrm{g})$ & - & + & + \\
\hline \multicolumn{4}{|l|}{ Enzyme activity (API ZYM) } \\
\hline Esterase lipase (C8) & + & $\mathrm{W}$ & + \\
\hline Valine arylamidase & + & $\mathrm{w}$ & + \\
\hline Cystine arylamidase & - & $\mathrm{W}$ & - \\
\hline
\end{tabular}

Table 1. cont.

\begin{tabular}{|cccc|}
\hline Characteristic & $\mathbf{1}$ & $\mathbf{2}$ & $\mathbf{3}$ \\
\hline$\alpha$-Glucosidase & - & - & + \\
$\beta$-Glucosidase & - & $\mathrm{w}$ & - \\
$N$-Acetyl- $\beta$-glucosaminidase & - & - & + \\
DNA G+C content $($ mol\%) & 35.7 & 35.7 & 34.5 \\
\hline
\end{tabular}

using the bioMérieux Gram stain kit according to the manufacturer's instructions. Growth under anaerobic conditions was determined after incubation in an anaerobic chamber (Forma 1029; $\mathrm{N}_{2} / \mathrm{CO}_{2} / \mathrm{H}_{2}, 86: 7: 7$ ) on MA and on MA supplemented with potassium nitrate $(0.1 \%$, $\mathrm{w} / \mathrm{v})$, both of which had been prepared anaerobically under a nitrogen atmosphere. Growth at 4, 10, 20, 25, 28, 30, 34 and $35{ }^{\circ} \mathrm{C}$ was measured on $\mathrm{MA}$. The $\mathrm{pH}$ range for growth was investigated in marine broth 2216 (MB, Difco) adjusted to $\mathrm{pH} 4.5-10.0$ (in increments of $0.5 \mathrm{pH}$ units) by using sodium acetate/acetic acid and $\mathrm{Na}_{2} \mathrm{CO}_{3}$ buffers. The $\mathrm{pH}$ was verified after autoclaving. Growth in the absence of $\mathrm{NaCl}$ and in the presence of $0.5,1.0,2.0$ and $3.0 \%(\mathrm{w} / \mathrm{v}) \mathrm{NaCl}$ was investigated in trypticase soy broth prepared according to the formula of the Difco medium except that $\mathrm{NaCl}$ was omitted and that $0.45 \%(\mathrm{w} / \mathrm{v})$ $\mathrm{MgCl}_{2} \cdot 6 \mathrm{H}_{2} \mathrm{O}$ was added. Growth in the presence of $2.0-$ $7.0 \%$ (final concentration, w/v, in increments of $1.0 \%$ ) $\mathrm{NaCl}$ was investigated in $\mathrm{MB}$. Catalase and oxidase activities were determined as described by Cowan \& Steel (1965). Hydrolysis of casein, starch, hypoxanthine, tyrosine and xanthine was tested on MA using the substrate concentrations described by Cowan \& Steel (1965). Nitrate reduction and hydrolysis of aesculin, gelatin, Tweens 20, 40, 60 and 80 and urea were investigated as described previously (Lányí, 1987) with the modification that artificial seawater was used for the preparation of media. The artificial seawater contained $\left(1^{-1}\right.$ distilled water) $23.6 \mathrm{~g} \mathrm{NaCl}, 0.64 \mathrm{~g} \mathrm{KCl}, 4.53 \mathrm{~g} \mathrm{MgCl}_{2} .6 \mathrm{H}_{2} \mathrm{O}$, $5.94 \mathrm{~g} \mathrm{MgSO}_{4} \cdot 7 \mathrm{H}_{2} \mathrm{O}$ and $1.3 \mathrm{~g} \mathrm{CaCl}_{2} \cdot 2 \mathrm{H}_{2} \mathrm{O}$ (Bruns et al., 2001). $\mathrm{H}_{2} \mathrm{~S}$ production was tested as described previously (Bruns et al., 2001). The presence of flexirubin-type pigments was investigated as described by Reichenbach (1992). Acid production from carbohydrates was tested as described by Leifson (1963). Utilization of substrates as sole carbon and energy sources was tested according to the method of Yurkov et al. (1994). Susceptibility to antibiotics was tested on MA plates using antibiotic discs (Advantec) containing the following amounts: ampicillin $(10 \mu \mathrm{g})$, carbenicillin $(100 \mu \mathrm{g})$, cephalothin $(30 \mu \mathrm{g})$, chloramphenicol $(100 \mu \mathrm{g})$, gentamicin $(30 \mu \mathrm{g})$, kanamycin $(30 \mu \mathrm{g})$, lincomycin $(15 \mu \mathrm{g})$, neomycin $(30 \mu \mathrm{g})$, novobiocin $(5 \mu \mathrm{g})$, oleandomycin $(15 \mu \mathrm{g})$, penicillin $\mathrm{G}(20 \mathrm{U})$, polymyxin $\mathrm{B}(100 \mathrm{U})$, streptomycin $(50 \mu \mathrm{g})$ and tetracycline $(30 \mu \mathrm{g})$. The API ZYM system (bioMérieux) incubated at $30{ }^{\circ} \mathrm{C}$ for $8 \mathrm{~h}$ was used to investigate enzyme activities. Morphological, cultural, physiological and biochemical properties of strain $\mathrm{HWR}-17^{\mathrm{T}}$ are given in the species description and in Table 1. 
Cell biomass of strain HWR $-17^{\mathrm{T}}$ for DNA extraction and for the analyses of isoprenoid quinones and polar lipids was obtained from cultures grown at $30{ }^{\circ} \mathrm{C}$ in $\mathrm{MB}$. Cell biomass of M. gromovii KCTC $12570^{\mathrm{T}}$ and M. fucanivorans DSM $18792^{\mathrm{T}}$ for DNA extraction and polar lipid analysis was obtained from cultures grown at $30{ }^{\circ} \mathrm{C}$ in $\mathrm{MB}$. Chromosomal DNA was isolated and purified according to the method described by Yoon et al. (1996), with the exception that RNase T1 was used in combination with RNase A to minimize contamination with RNA. The $16 \mathrm{~S}$ rRNA gene was amplified using a PCR with two universal primers as described previously (Yoon et al., 1998) and the PCR products were purified by using a QIAquick PCR purification kit (Qiagen). Sequencing of the amplified 16S rRNA gene and phylogenetic analysis were performed as described by Yoon et al. (2003). Isoprenoid quinones were extracted according to the method of Komagata \& Suzuki (1987) and analysed using reversed-phase HPLC and a YMC ODS-A $(250 \times 4.6 \mathrm{~mm})$ column. For cellular fatty acid analysis, cell mass of strain HWR- $17^{\mathrm{T}}$, M. gromovii KCTC $12570^{\mathrm{T}}$ and M. fucanivorans DSM $18792^{\mathrm{T}}$ was harvested from MA plates after cultivation for 5 days at $30{ }^{\circ} \mathrm{C}$. Fatty acids were saponified, methylated and extracted using the standard protocol of the Sherlock Microbial Identification System, version 4.0 (MIDI). The fatty acids were analysed by GC (Hewlett Packard 6890) and identified by using the TSBA40 database of the Microbial Identification System (Sasser, 1990). Polar lipids were extracted according to the procedures described by Minnikin et al. (1984) and identified by two-dimensional TLC followed by spraying with the appropriate detection reagents (Minnikin et al., 1984; Komagata \& Suzuki, 1987). The DNA G + C content was determined by the method of Tamaoka \& Komagata (1984) with the modification that DNA was hydrolysed and the resultant nucleotides were analysed by reversed-phase HPLC equipped with a YMC ODS-A $(250 \times 4.6 \mathrm{~mm})$ column. The nucleotides were eluted with a mixture of $0.55 \mathrm{M} \mathrm{NH}_{4} \mathrm{H}_{2} \mathrm{PO}_{4}(\mathrm{pH} 4.0)$ and acetonitrile $(40: 1, \mathrm{v} / \mathrm{v})$, at a flow rate of $1 \mathrm{ml} \mathrm{min}^{-1}$ at room temperature, and detected by absorbance at $270 \mathrm{~nm}$. DNA-DNA hybridization was performed fluorometrically at $45{ }^{\circ} \mathrm{C}$ by the method of Ezaki et al. (1989) using photobiotin-labelled DNA probes and microdilution wells. Hybridization was performed with five replications for each sample; the highest and lowest values obtained for each sample were excluded and the means of the remaining three values are quoted as DNA-DNA relatedness values.

The almost-complete 16S rRNA gene sequence of strain HWR $-17^{\mathrm{T}}$ comprised $1471 \mathrm{nt}$, representing approximately $96 \%$ of the Escherichia coli $16 \mathrm{~S}$ rRNA gene sequence. In the phylogenetic tree reconstructed using the neighbourjoining algorithm, strain HWR- $17^{\mathrm{T}}$ joined the cluster comprising the type strains of the two Mariniflexile species with a bootstrap resampling value of $99.9 \%$ (Fig. 1). The relationships among strain $\mathrm{HWR}-17^{\mathrm{T}}$ and the two Mariniflexile type strains were maintained in trees reconstructed using the maximum-likelihood and maximumparsimony algorithms (Fig. 1). Strain HWR $-17^{\mathrm{T}}$ exhibited 16S rRNA gene sequence similarity of 97.1 and $97.2 \%$ to the type strains of $M$. gromovii and M. fucanivorans, respectively, and less than $95.7 \%$ similarity to those of the other species used in the phylogenetic analysis.

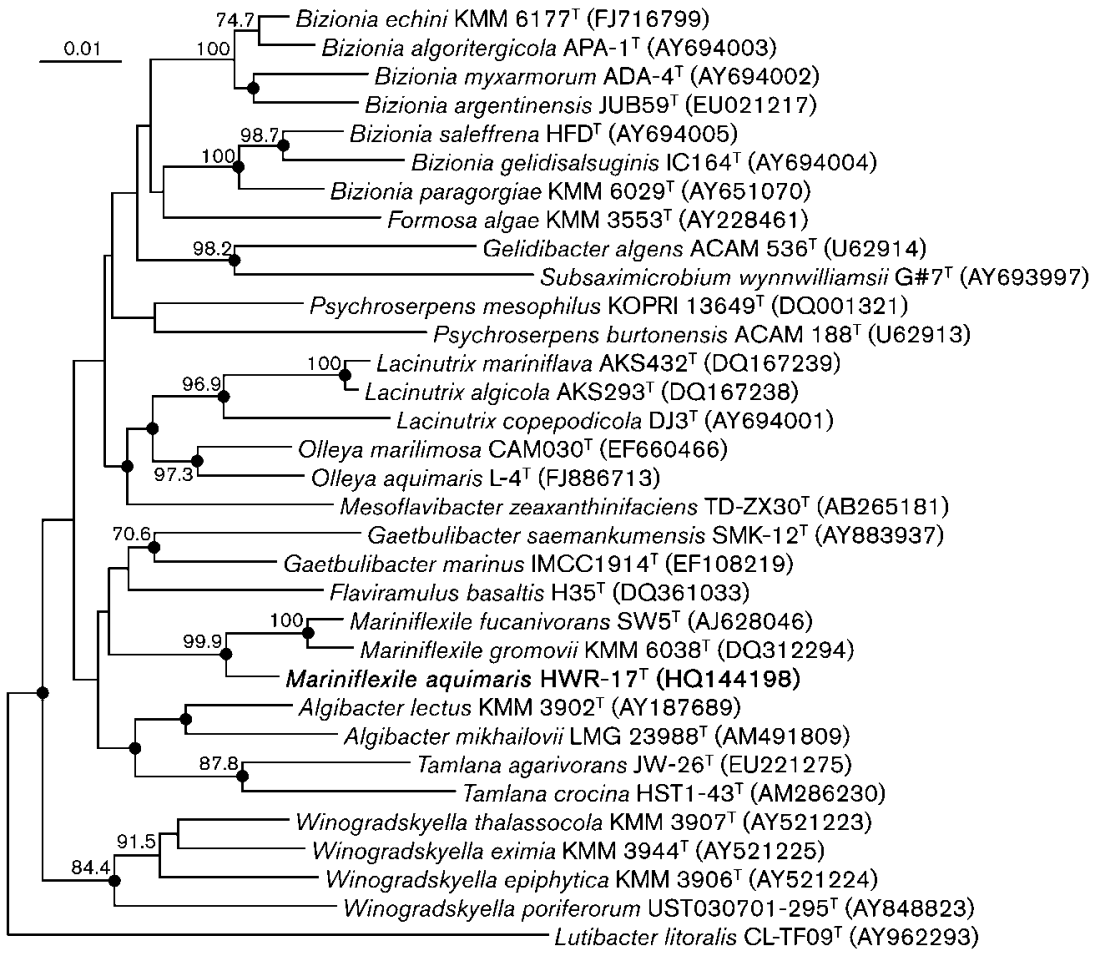

Fig. 1. Neighbour-joining tree based on $16 \mathrm{~S}$ rRNA gene sequences showing the phylogenetic positions of Mariniflexile aquimaris sp. nov. HWR-1 $7^{\top}$, other Mariniflexile species and representatives of some related taxa. Only bootstrap values (expressed as percentages of 1000 replications) greater than $70 \%$ are shown at branching points. Filled circles indicate that the corresponding nodes were also recovered in trees generated with the maximum-likelihood and maximum-parsimony algorithms. The sequence of Lutibacter litoralis CL-TF09 ${ }^{\top}$ was used as an outgroup. Bar, 0.01 substitutions per nucleotide position. 
The predominant isoprenoid quinone detected in strain HWR- $17^{\mathrm{T}}$ was menaquinone-6 (MK-6), in line with members of the genus Mariniflexile (Nedashkovskaya et al., 2006) and all other members of the family Flavobacteriaceae (Bernardet, 2011). The complete cellular fatty acid profiles of strain HWR- $17^{\mathrm{T}}$ and the type strains of the two Mariniflexile species grown and analysed under identical conditions in this study are compared in Table 2 . The major fatty acid ( $>10 \%$ of the total fatty acids) found in strain HWR- $17^{\mathrm{T}}$ was iso- $\mathrm{C}_{15: 0}(24.8 \%)$ (Table 2). The fatty acid profiles of the three strains were similar, though there were also differences in the proportions of some fatty acids, particularly $\mathrm{C}_{15: 0}$, iso- $\mathrm{C}_{15: 1} \mathrm{G}$ and $\mathrm{C}_{15: 1} \omega 6 c$. Strain HWR $-17^{\mathrm{T}}$ contained phosphatidylethanolamine, an unidentified aminolipid and an unidentified lipid (L1) as the major polar lipids; it also contained minor amounts of three additional unidentified lipids (L2-L4) (Fig. 2). This

Table 2. Cellular fatty acid compositions of strain HWR-17 and the type strains of the two Mariniflexile species

Strains: 1 , M. aquimaris sp. nov. HWR-17 ${ }^{\mathrm{T}}$; 2. M. gromovii KCTC $12570^{\mathrm{T}}$; 3, M. fucanivorans DSM $18792^{\mathrm{T}}$. All data were obtained in this study. Values are percentages of total fatty acids; fatty acids that represented $<1.0 \%$ in all strains have been omitted. tr, Trace $(<1.0 \%) ;-$, not detected; TBSA, tuberculostearic acid.

\begin{tabular}{|c|c|c|c|}
\hline Fatty acid & 1 & 2 & 3 \\
\hline \multicolumn{4}{|l|}{ Straight-chain saturated } \\
\hline $\mathrm{C}_{15: 0}$ & 3.6 & 18.0 & 8.0 \\
\hline $\mathrm{C}_{16: 0}$ & $\operatorname{tr}$ & 1.1 & $\operatorname{tr}$ \\
\hline \multicolumn{4}{|l|}{ Straight-chain unsaturated } \\
\hline $\mathrm{C}_{15: 1} \omega 6 c$ & 2.4 & 4.3 & 11.0 \\
\hline $\mathrm{C}_{17: 1} \omega 6 c$ & $\operatorname{tr}$ & $\operatorname{tr}$ & 3.9 \\
\hline \multicolumn{4}{|l|}{ Branched } \\
\hline iso- $\mathrm{C}_{14: 0}$ & 1.9 & 1.2 & 1.8 \\
\hline iso- $\mathrm{C}_{15: 0}$ & 24.8 & 18.3 & 15.4 \\
\hline anteiso- $\mathrm{C}_{15: 0}$ & 7.2 & 5.6 & 6.2 \\
\hline iso- $\mathrm{C}_{15: 1} \mathrm{G}^{*}$ & 6.4 & 12.9 & 2.0 \\
\hline iso- $\mathrm{C}_{16: 0}$ & 1.2 & $\operatorname{tr}$ & $\operatorname{tr}$ \\
\hline iso- $\mathrm{C}_{16: 1} \mathrm{H}^{*}$ & 1.4 & $\operatorname{tr}$ & 1.3 \\
\hline iso- $\mathrm{C}_{17: 1} \omega 9 c$ & 1.7 & $\operatorname{tr}$ & $\operatorname{tr}$ \\
\hline \multicolumn{4}{|l|}{ Hydroxy } \\
\hline $\mathrm{C}_{15: 0} 2-\mathrm{OH}$ & 1.7 & 1.4 & 2.3 \\
\hline $\mathrm{C}_{15: 0} 3-\mathrm{OH}$ & 2.8 & 2.7 & 5.0 \\
\hline iso- $\mathrm{C}_{15: 0} 3-\mathrm{OH}$ & 9.3 & 6.1 & 8.9 \\
\hline iso- $\mathrm{C}_{16: 0} 3-\mathrm{OH}$ & 9.2 & 5.0 & 7.8 \\
\hline $\mathrm{C}_{17: 0} 2-\mathrm{OH}$ & 2.3 & 1.3 & 2.9 \\
\hline iso- $\mathrm{C}_{17: 0} 3-\mathrm{OH}$ & 9.6 & 9.1 & 7.5 \\
\hline \multicolumn{4}{|l|}{ Others } \\
\hline 10-Methyl C 18:0 $_{\text {(TBSA) }}$ & $\operatorname{tr}$ & - & 1.3 \\
\hline Summed feature $3 \dagger$ & 7.2 & 4.0 & 6.1 \\
\hline
\end{tabular}

${ }^{\star}$ Double bond position indicated by a capital letter is unknown. $\dagger$ Summed features represent groups of two or three fatty acids that could not be separated by GLC with the MIDI system. Summed feature 3 contained $\mathrm{C}_{16: 1} \omega 7 c$ and/or iso- $\mathrm{C}_{15: 0} 2-\mathrm{OH}$. polar lipid profile was very similar to those of $M$. gromovii KCTC $12570^{\mathrm{T}}$ and M. fucanivorans DSM $18792^{\mathrm{T}}$. The DNA $\mathrm{G}+\mathrm{C}$ content of strain HWR $-17^{\mathrm{T}}$ was $35.7 \mathrm{~mol} \%$, a value in line with those reported for the two Mariniflexile species (Nedashkovskaya et al., 2006; Barbeyron et al., 2008). Hence, it is appropriate to classify strain $\mathrm{HWR}-17^{\mathrm{T}}$ as a member of the genus Mariniflexile, as shown by phylogenetic inference and the absence of differentiating chemotaxonomic properties from the two described Mariniflexile species.

Strain HWR- $17^{\mathrm{T}}$ exhibited mean DNA-DNA relatedness values of 11 and $10 \%$ with M. gromovii KCTC $12570^{\mathrm{T}}$ and M. fucanivorans DSM $18792^{\mathrm{T}}$, respectively. Strain HWR$17^{\mathrm{T}}$ was distinguishable from these two strains by differences in several phenotypic characteristics, as shown in Table 1. These differences, in combination with phylogenetic and genetic distinctiveness between strain HWR $-17^{\mathrm{T}}$ and the two Mariniflexile species, suggest that the novel strain represents a novel species of the genus Mariniflexile (Wayne et al., 1987; Stackebrandt \& Goebel, 1994), for which the name Mariniflexile aquimaris sp. nov. is proposed. An emended description of the genus Mariniflexile is also proposed on the basis of new data obtained in this study.

\section{Emended description of the genus Mariniflexile Nedashkovskaya et al. 2006}

Mariniflexile [Ma.ri.ni.fle'xi.le. L. adj. marinus marine; L. part. adj. flexilis $-e$ pliant, pliable, flexible; N.L. neut. n. Mariniflexile a flexible marine (bacterium)].

The description of the genus Mariniflexile is as given by Nedashkovskaya et al. (2006) with the following amendments. Motile by gliding or non-gliding. Optimal growth temperature is $25-30{ }^{\circ} \mathrm{C}$. Oxidase activity is negative. The major polar lipids are phosphatidylethanolamine, an unidentified aminolipid and an unidentified lipid.

\section{Description of Mariniflexile aquimaris sp. nov.}

Mariniflexile aquimaris (a.qui.ma' ris. L. n. aqua water; L. gen. n. maris of the sea; N.L. gen. n. aquimaris of the water of the sea).

Cells are Gram-staining-negative, non-flagellated, nongliding and rod-shaped, approximately $0.2-0.5 \mu \mathrm{m}$ in diameter and $2.0-8.0 \mu \mathrm{m}$ long. Colonies on MA are circular, convex, smooth, glistening and yellow, $0.2-$ $1.0 \mathrm{~mm}$ in diameter after incubation for 3 days at $30{ }^{\circ} \mathrm{C}$. Optimal growth temperature is $30^{\circ} \mathrm{C}$; growth occurs at 10 and $34{ }^{\circ} \mathrm{C}$, but not at 4 or $35{ }^{\circ} \mathrm{C}$. Optimal growth at $\mathrm{pH}$ 7.0-8.0; growth occurs at $\mathrm{pH} 5.5$, but not at $\mathrm{pH} 5.0$. Growth occurs in the presence of $0-5 \%(w / v) ~ N a C l$ with an optimum of approximately $2.0 \%(\mathrm{w} / \mathrm{v}) \mathrm{NaCl} . \mathrm{Mg}^{2+}$ ions are required for growth. Anaerobic growth does not occur on MA or on MA supplemented with nitrate. $\mathrm{H}_{2} \mathrm{~S}$ is not produced. Flexirubin-type pigments are not produced. Susceptible to cephalotin, gentamicin, neomycin, penicillin 


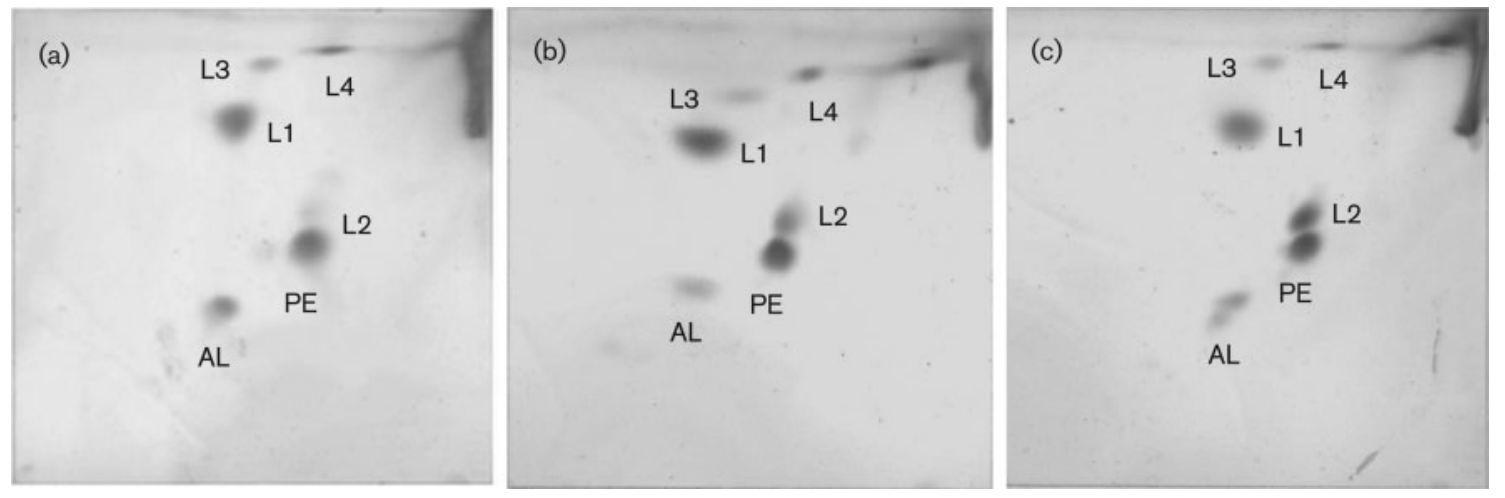

Fig. 2. Thin-layer chromatograms of total polar lipids of $M$. aquimaris sp. nov. HWR-17 ${ }^{\top}$ (a), M. gromovii KCTC $12570^{\top}$ (b) and M. fucanivorans DSM $18792^{\top}$ (c). Spots were revealed using molybdatophosphoric acid, molybdenum blue, ninhydrin and $\alpha-$ naphthol reagents. PE, Phosphatidylethanolamine; AL, unidentified aminolipid; L1-L4, unidentified lipids.

$\mathrm{G}$ and polymyxin $\mathrm{B}$, but not to ampicillin, carbenicillin, chloramphenicol, kanamycin, lincomycin, novobiocin, oleandomycin, streptomycin or tetracycline. The predominant menaquinone is MK-6 and the major fatty acid ( $>10 \%$ of the total fatty acids) is iso- $\mathrm{C}_{15: 0}$. In addition to the major polar lipids given in the emended genus description, three unidentified lipids are present in minor amounts. The DNA G+C content of the type strain is $35.7 \mathrm{~mol} \%$. Other phenotypic characteristics are given in Table 1 .

The type strain, HWR $-17^{\mathrm{T}}$ (= KCTC $23346^{\mathrm{T}}=$ CCUG $60529^{\mathrm{T}}$ ), was isolated from seawater off Hwang-do, an island of Korea.

\section{Acknowledgements}

This work was supported by the 21C Frontier Program of Microbial Genomics and Applications (grant no. 11-2008-00-002-00) and the Program for Collection, Management and Utilization of Biological Resources (grant no. M10867010003) from the Ministry of Education, Science and Technology (MEST) of the Republic of Korea.

\section{References}

Barbeyron, T., L'Haridon, S., Michel, G. \& Czjzek, M. (2008). Mariniflexile fucanivorans sp. nov., a marine member of the Flavobacteriaceae that degrades sulphated fucans from brown algae. Int J Syst Evol Microbiol 58, 2107-2113.

Bernardet, J.-F. (2011). Family I. Flavobacteriaceae Reichenbach 1992. In Bergey's Manual of Systematic Bacteriology, 2nd edn, vol. 4, pp. 106-111. Edited by N. R. Krieg, W. Ludwig, W. B. Whitman, B. P. Hedlund, B. J. Paster, J. T. Staley, N. Ward, D. Brown \& A. Parte. New York: Springer.

Bowman, J. P. (2000). Description of Cellulophaga algicola sp. nov., isolated from the surfaces of Antarctic algae, and reclassification of Cytophaga uliginosa (ZoBell and Upham 1944) Reichenbach 1989 as Cellulophaga uliginosa comb. nov. Int J Syst Evol Microbiol 50, 18611868.

Bruns, A., Rohde, M. \& Berthe-Corti, L. (2001). Muricauda ruestringensis gen. nov., sp. nov., a facultatively anaerobic, appendaged bacterium from German North Sea intertidal sediment. Int J Syst Evol Microbiol 51, 1997-2006.

Cowan, S. T. \& Steel, K. J. (1965). Manual for the Identification of Medical Bacteria. London: Cambridge University Press.

Ezaki, T., Hashimoto, Y. \& Yabuuchi, E. (1989). Fluorometric deoxyribonucleic acid-deoxyribonucleic acid hybridization in microdilution wells as an alternative to membrane filter hybridization in which radioisotopes are used to determine genetic relatedness among bacterial strains. Int J Syst Bacteriol 39, 224-229.

Komagata, K. \& Suzuki, K. (1987). Lipid and cell-wall analysis in bacterial systematics. Methods Microbiol 19, 161-207.

Lányí, B. (1987). Classical and rapid identification methods for medically important bacteria. Methods Microbiol 19, 1-67.

Leifson, E. (1963). Determination of carbohydrate metabolism of marine bacteria. J Bacteriol 85, 1183-1184.

Minnikin, D. E., O’Donnell, A. G., Goodfellow, M., Alderson, G., Athalye, M., Schaal, A. \& Parlett, J. H. (1984). An integrated procedure for the extraction of bacterial isoprenoid quinones and polar lipids. J Microbiol Methods 2, 233-241.

Nedashkovskaya, O. I., Kim, S. B., Kwak, J., Mikhailov, V. V. \& Bae, K. S. (2006). Mariniflexile gromovii gen. nov., sp. nov., a gliding bacterium isolated from the sea urchin Strongylocentrotus intermedius. Int J Syst Evol Microbiol 56, 1635-1638.

Reichenbach, H. (1992). The order Cytophagales. In The Prokaryotes. A Handbook on the Biology of Bacteria: Ecophysiology, Isolation, Identification, Applications, 2nd edn, pp. 3631-3675. Edited by A. Balows, H. G. Trüper, M. Dworkin, W. Harder \& K. H. Schleifer. New York: Springer.

Sasser, M. (1990). Identification of bacteria by gas chromatography of cellular fatty acids, MIDI Technical Note 101. Newark, DE: MIDI Inc.

Stackebrandt, E. \& Goebel, B. M. (1994). Taxonomic note: a place for DNA-DNA reassociation and 16S rRNA sequence analysis in the present species definition in bacteriology. Int J Syst Bacteriol 44, 846849.

Tamaoka, J. \& Komagata, K. (1984). Determination of DNA base composition by reversed-phase high-performance liquid chromatography. FEMS Microbiol Lett 25, 125-128.

Wayne, L. G., Brenner, D. J., Colwell, R. R., Grimont, P. A. D., Kandler, O., Krichevsky, M. I., Moore, L. H., Moore, W. E. C., Murray, R. G. E. \& other authors (1987). Report of the ad hoc committee on reconciliation 
of approaches to bacterial systematics. Int J Syst Bacteriol 37, 463464.

Yoon, J.-H., Kim, H., Kim, S.-B., Kim, H.-J., Kim, W. Y., Lee, S. T., Goodfellow, M. \& Park, Y.-H. (1996). Identification of Saccharomonospora strains by the use of genomic DNA fragments and rRNA gene probes. Int J Syst Bacteriol 46, 502-505.

Yoon, J.-H., Lee, S. T. \& Park, Y.-H. (1998). Inter- and intraspecific phylogenetic analysis of the genus Nocardioides and related taxa based on 16 SDNA sequences. Int J Syst Bacteriol 48, 187-194.
Yoon, J.-H., Kang, K. H. \& Park, Y.-H. (2003). Psychrobacter jeotgali sp. nov., isolated from jeotgal, a traditional Korean fermented seafood. Int J Syst Evol Microbiol 53, 449-454.

Yurkov, V., Stackebrandt, E., Holmes, A., Fuerst, J. A., Hugenholtz, P., Golecki, J., Gad'on, N., Gorlenko, V. M., Kompantseva, E. I. \& Drews, G. (1994). Phylogenetic positions of novel aerobic, bacteriochlorophyll a-containing bacteria and description of Roseococcus thiosulfatophilus gen. nov., sp. nov., Erythromicrobium ramosum gen. nov., sp. nov., and Erythrobacter litoralis sp. nov. Int J Syst Bacteriol 44, 427-434. 